\title{
Kuraklık Stresinde Buğday Genotiplerinde Verim Komponentleri ve Antioksidan Enzim Metabolizmasında Değişimler
}

\author{
İmren KUTLU ${ }^{1}$ \\ Ece TURHAN ${ }^{2}$ \\ Özcan YORGANCILAR ${ }^{3}$ \\ ${ }^{1}$ Eskişehir Osmangazi Üniversitesi Ziraat Fakültesi, Biyosistem Mühendisliği Bölümü, Eskişehir \\ ${ }^{2}$ Eskişehir Osmangazi Üniversitesi Ziraat Fakültesi, Tarımsal Biyoteknoloji Bölümü, Eskişehir \\ ${ }^{3}$ Geçit Kuşağı Tarımsal Araştırma Enstitüsü, Eskişehir \\ $\bowtie$ : ikutlu@ogu.edu.tr
}

Aysel YORGANCILAR ${ }^{3}$

Geliş (Received): 04.11.2017

Kabul (Accepted): 15.12.2017

\begin{abstract}
ÖZET: Bu çalışma ile ekmeklik buğday genotiplerinin kuraklık stresi altındaki verim bileşenlerinin ve enzim aktivitelerinin istikrarı ile bunlar arasındaki ilişkinin tanımlanması amaçlanmıştır. Deneme, Eskişehir şartlarında, 2013-2014 üretim sezonunda, 9 ekmeklik buğday çeşidi ve 7 doubled haploid buğday genotipi ile yürütülmüştür. Genotipler çiçeklenme süresi, başak boyu, başakta tane sayısı, başakta tane ağırlığı, bin tane ağırlığı ve yaprak dokularındaki katalaz (CAT) ve glutatiyon redüktaz (GR) enzim aktivitelerindeki değişimler yönünden analiz edilmişlerdir. Bu özelliklere ait stres duyarlılık indeksi (SSI) hesaplanmış ve enzim aktiviteleri ile verim komponentleri arasındaki ikili ilişkiler belirlenmiştir. Kuraklık stresi altında, başak boyunda \%57, başakta tane sayısında \%86 ve başakta tane ağırlığında ise \%88'e varan azalmalar belirlenmiş, ortalama CAT aktivitesi önemli ölçüde artarken, GR aktivitesi etkilenmemiştir. Kuru koşullarda CAT ve GR aktivitelerinde en fazla artışın Krasunia, Bezostaja-1 ve DH19 genotiplerinde olduğu belirlenmiştir. Glutatiyon redüktaz ile bin tane ağırlığı arasında negatif ve önemli korelasyon saptanırken, CAT enzim aktivitesi bin tane ağırlığı dışındaki tüm özelliklerle negatif ve önemli korelasyon göstermiştir. Bu sonuçlar, özellikle CAT aktivitesinin kuraklıkla değişimininin buğdayın kurak koşullardaki veriminin korunmasına ve dolayısıyla kuraklık toleransının geliştirilmesine katkıda bulunabileceğini düşündürmektedir. Ayrıca tüm başak özelliklerinde SSI bakımından 1'den küçük değere sahip olan ve stres koşullarında antioksidan enzim aktivitelerini koruyabilen DH6 ve DH19 genotipleri ile Bezostaja-1 çeşidinin, kuraklığa toleransı geliştirmek için yapılacak ıslah programlarında ebeveyn olarak kullanılabileceği sonucuna varılmıştır.
\end{abstract}

Anahtar Kelimeler: Ekmeklik buğday, glutatiyon redüktaz, katalaz, kuraklık, stres duyarlılık indeksi.

\section{Changes in Yield Components and Antioxidant Enzyme Metabolism of Wheat Genotypes in Drought Stress}

ABTRACT: In this study, it is aimed to define the stability of yield component and enzyme activities of wheat genotypes under drought stress and their relationships with each other. The research was conducted with 9 bread wheat cultivars and 7 doubled haploid wheat genotypes in 2013-2014 growing season in Eskişehir. Genotypes were analysed to variance of flowering time, spike length, grains per spike, grain weight, 100-kernel weight and catalase (CAT) and glutathione reductase (GR) enzyme activities. Stress susceptibility index (SSI) was calculated belong to these traits and determined relationships between enzyme activities and yield components. Under drought stress, spike length, grains per spike and grain weight were decreased approximately $57 \%, 86 \%$ and $88 \%$, respectively. Mean CAT activity was significantly increased while GR activity was not affected. The most increasing of CAT and GR activity at dry condition was determined in Krasunia, Bezostaja-1 and DH19 genotypes. Negative and significant correlation was found between GR and thousand kernel weight while there was negative and significant correlation between CAT and other yield components. These results suggest that, in particular, the change of CAT activity by drought may contribute to preservation of the wheat yield in dry conditions and thus to the improvement of drought tolerance. In addition, DH6, DH19 and Bezostaja-1, have SSI value of less than 1 in all of spike traits and maintain antioxidant enzyme activities under stress conditions, can be used as a parent in breeding programs to improve drought tolerance.

Key Words: Bread wheat, catalase, drought, glutathione reductase, stress susceptibility index.

\section{GIRIŞ}

Buğdayda kuraklığa bağlı olarak verimde azalma, tarımsal üretimde sürdürülebilirliği ve dünya gida güvenliğini tehdit etmektedir. Dünyada buğday ekim alanlarının yaklaşık \%55'i periyodik olarak kuraklıktan etkilenmekte ve bu alanlarda buğday verimi sulanır koşullardaki verim potansiyelinden \% 50-90 daha az olabilmektedir (Richards ve ark., 2001). Ülkemizde, özellikle de Orta Anadolu ve geçit bölgelerinde, buğday yetiştiriciliği büyük ölçüde yağışa bağımlı olarak yapılmaktadır. Yağışların yetersiz olması ve düzensiz dağılımından dolayı buğday bitkisi farklı gelişme dönemlerinde kuraklıktan etkilenebilmektedir. Ülkemiz tahıl üretim alanlarında daha sık karşılaşılan bir durum olan çiçeklenme sonrası kuraklık (Öztürk, 1999); metre karede fertil başak sayısı, başakta tane sayısı veya tane ağırlığını azaltarak verimi olumsuz olarak etkilemektedir. Ülkemizde kuraklığa toleransı yüksek 
buğday çeşitleri geliştirmek amaciyla yürütülen sslah programlarında, çoğunlukla erkencilik özelliği ile birlikte bazı morfolojik özellikler ve verim komponentleri de erken generasyon seleksiyon kriterleri olarak kullanılmaktadır. Kurak koşullar altında sadece verim bakımından yapılacak seleksiyonun başarısının, tane veriminin kalıtım derecesinin düşük olması nedeniyle yetersiz olacağı (Blum, 1988), bu nedenle stres koşulları altında verim azalmalarını engelleyen belirli bazı özelliklerin, tane verimiyle kombine edilmesi gerektiği ileri sürülmüştür (Sharma ve Thakur, 2004).

Diğer taraftan bitkiler stres koşullarına maruz kaldıklarında ortaya çıkan biyokimyasal değişimlerden birisi aktif oksijen türlerinin (AOT) üretimidir (Allen, 1995). Herhangi bir koruma mekanizmasının olmadığ durumlarda AOT'leri lipit, protein ve nükleik asitlerde oksidatif zararlanma yoluyla normal metabolizmay ciddi şekilde zararlandırabilmektedir. Kurağa toleranslı bitkiler AOT'lerinin zararlı etkilerini yok edebilmek için bir dizi enzimatik ve enzimatik olmayan antioksidan sistemler geliştirmişlerdir (Farooq ve ark., 2009). Daha önce yapılan çalışmalarda buğdayın antioksidan enzim seviyelerinin kuraklık stresine bağlı olarak genellikle arttığ ve enzim aktivitelerinin genotiplere ve bitkinin gelişme dönemine göre farklılık gösterdiği belirlenmiştir (Simova-Stoilova ve ark., 2009; Osipava ve ark., 2011; Huseynova ve ark., 2016). Çoğunlukla peroksizomlarda bulunan CAT hidrojen peroksit $\left(\mathrm{H}_{2} \mathrm{O}_{2}\right)^{\prime} \mathrm{i} \mathrm{H}_{2} \mathrm{O}$ ve $\mathrm{O}_{2}$ 'ye dönüştürür (Sudhakar ve ark., 2001). Askorbat peroksidaz ve GR, yeşil yapraklardaki $\mathrm{H}_{2} \mathrm{O}_{2}$ detoksifikasyonundan sorumludur. Glutatyon redüktazın stres sırasında indirgenmiş glutatyon (GSH) havuzunun korunmasinda merkezi bir role sahip olduğu bilinmektedir (Pastori ve ark., 2000). Etkili seleksiyon kriterlerinin tespiti amaciyla yapılan çalışmalarda çeşitlerin sulu ve kuru koşullar altındaki performaslarının belirlenmesi, kuraklığa toleransı yüksek çeşitlerin ortaya çıkarılmasında bir başlangıç noktası olarak görülmektedir (Clarke ve ark. 1992). Diğer taraftan antioksidan enzim aktivitesi ve stres toleransı arasında çok yakın bir ilişki olduğu da saptanmıştır (Sharma ve Dubey, 2005; Contour-Ansel ve ark., 2006). Bu nedenle bu çalışma ile ekmeklik buğday genotiplerinin kuraklık stresi altındaki verim bileşenlerinin istikrarı ve enzim aktivitelerinin değişimi ile bunlar arasındaki ilişkinin tanımlanması amaçlanmıştır.

\section{MATERYAL ve YÖNTEM}

$\mathrm{Bu}$ çalışma, 2013-2014 yetiştirme sezonunda Eskişehir Osmangazi Üniversitesi (ESOGÜ) Ziraat Fakültesi deneme alanında yürütülmüş̧ür. Araştırmanın yürütüldüğü ESOGÜ Ziraat Fakültesi deneme tarlalarında deneme yerine ait topraklar \% 1,38 organik madde, \% 5,8 kireç içermektedir. Tuzsuz ( $\% 0.08)$, tınlı ve hafif alkali ( $\mathrm{pH} 7,8)$ yapıdadır. Deneme yılı ve uzun yıllar ortalamasına ait toplam yağış sırasıyla $269,4 \mathrm{~mm}$ ve $329,7 \mathrm{~mm}$ olurken, ortalama sicaklık değerleri 9,69 ${ }^{\circ} \mathrm{C}$ ve $10,26{ }^{\circ} \mathrm{C}$ arasında değişmiştir.
Çalışmada; 9 ekmeklik buğday çeşidi (Altay 2000, Bezostaja-1, Esperia, Harmankaya 99, Kate A-1, Krasunia Odeska, Müfitbey, Nacibey, Syrena Odeska) ile 7 doubled haploid (DH) buğday hattı kullanılmıştır. Deneme, bölünmüş parseller deneme desenine göre, 3 tekrarlamalı olarak kuru ve sulu koşullarda kurulmuştur. Ekim işlemi, 9.10.2013 tarihinde $1 \mathrm{~m}$ uzunluğundaki parsellere, $30 \mathrm{~cm}$ sira aralığında, 4 sira olarak elle yapılmıştır. Kuru ve sulu denemede kullanılan gübre miktarları saf olarak dekara $6 \mathrm{~kg} \mathrm{~N}, 7 \mathrm{~kg} \mathrm{P}_{2} \mathrm{O}_{5}$ ve $12 \mathrm{~kg}$ $\mathrm{N}$ ve $9 \mathrm{~kg} \mathrm{P}_{2} \mathrm{O}_{5}$ şeklindedir, sulu denemede sapa kalkma ve çiçeklenme dönemi olmak üzere $2 \mathrm{kez}$ takviye sulama yapılmıştır.

Başak ölçümleri her parselden seçilen 10 adet başakta yapılmıştır. Stres duyarlılık indeksi (SSI) Fischer ve Maurer (1978)'a göre hesaplanmıştır. Antioksidan enzim aktivitelerinin analizi için çiçeklenme döneminde alınan bayrak yapraklar kullanılmıştır. Enzim aktivitelerinin belirlenmesi için yaklaşık $0.2-0.3$ g yaprak örneği kullanılmıştır. Ekstraksiyon çözeltisi olarak (Moran ve ark., 1994); CAT enzimi için; $0.1 \mathrm{mM}$ EDTA ve $0.1 \%$ Triton içeren $100 \mathrm{mM} \mathrm{K}-\mathrm{PO}_{4}$ çözeltisi ( $\mathrm{pH}$ 7.0) kullanılırken GR enzimi için; $0.1 \mathrm{mM}$ EDTA içeren $50 \mathrm{mM} \mathrm{K}-\mathrm{PO}_{4}(\mathrm{pH}$ 7.6) çözeltisi kullanılmışıtır. Tüm ekstraksiyon aşamaları $4^{\circ} \mathrm{C}$ 'de gerçekleştirilmiştir. Homojenize edilen örnekler CAT için $760 \mathrm{~g}$ de 10 dakika, GR için ise $15000 \mathrm{~g}$ de 15 dakika santrifüj edilmiştir. Elde edilen santrifügantların spektrofotmetrik ölçümleri CAT aktivitesi için Rao ve ark. (1996), GR aktivitesi için Cakmak ve Marschner (1992) esas alınarak gerçekleştirilmiştir.

Genotipler ve koşullar arasındaki farklılıkları belirlemek amaciyla yapılan varyans analizi, genotiplerin Duncan'a göre sinıflandırılması ve antioksidan enzim aktiviteleri ile verim komponentleri arasındaki korelasyon analizi IBM SPSS 20 istatistik programı kullanılarak yapılmıştır.

\section{BULGULAR ve TARTIŞMA}

Başak boyu, başakta tane sayısı ve ağırlı̆̆ özellikleri tane verimi üzerine etkide bulunan ve verim tahmini için kullanılan en önemli parametrelerdir (Tosun ve Yurtman, 1973). Araştırmada incelenen genotiplerin sulu ve kuru koşullardaki başak boyu, başakta tane sayısı ve tane ağırlığı özelliklerinin değişimi Çizelge 1'de verilmiştir. Kuru koşullar altında en yüksek başak boyu, başakta tane sayısı ve ağırlığı DH19 genotipinde belirlenirken sulu koşullarda en yüksek değer DH6 genotipinden elde edilmiştir. Kurak koşullarda Bezostaja-1 çeşidi en düşük \% azalış1 göstererek verimini koruyabilmiştir. Stres duyarlılık indeksi değeri 1'den küçük olan genotiplerin stres koşullarına daha toleranslı oldukları bilinmektedir (Fischer ve Maurer, 1978). Yapılan benzer çalışmalarda ekmeklik buğdayda başak özelliklerinin, farklı gelişme dönemlerinde görülen kuraklık stresi altında azalma gösterdiği ve özellikle başakta tane ağırlığının kurak koşullara daha hassas olduğu belirtilmiştir (Dencic ve ark. 2000; Aydoğan ve Sade, 2017). 
Çizelge 1. Kuru ve sulu koşullarda genotiplerin başak özelliklerinin değişimi ve stres duyarlılık indeksleri

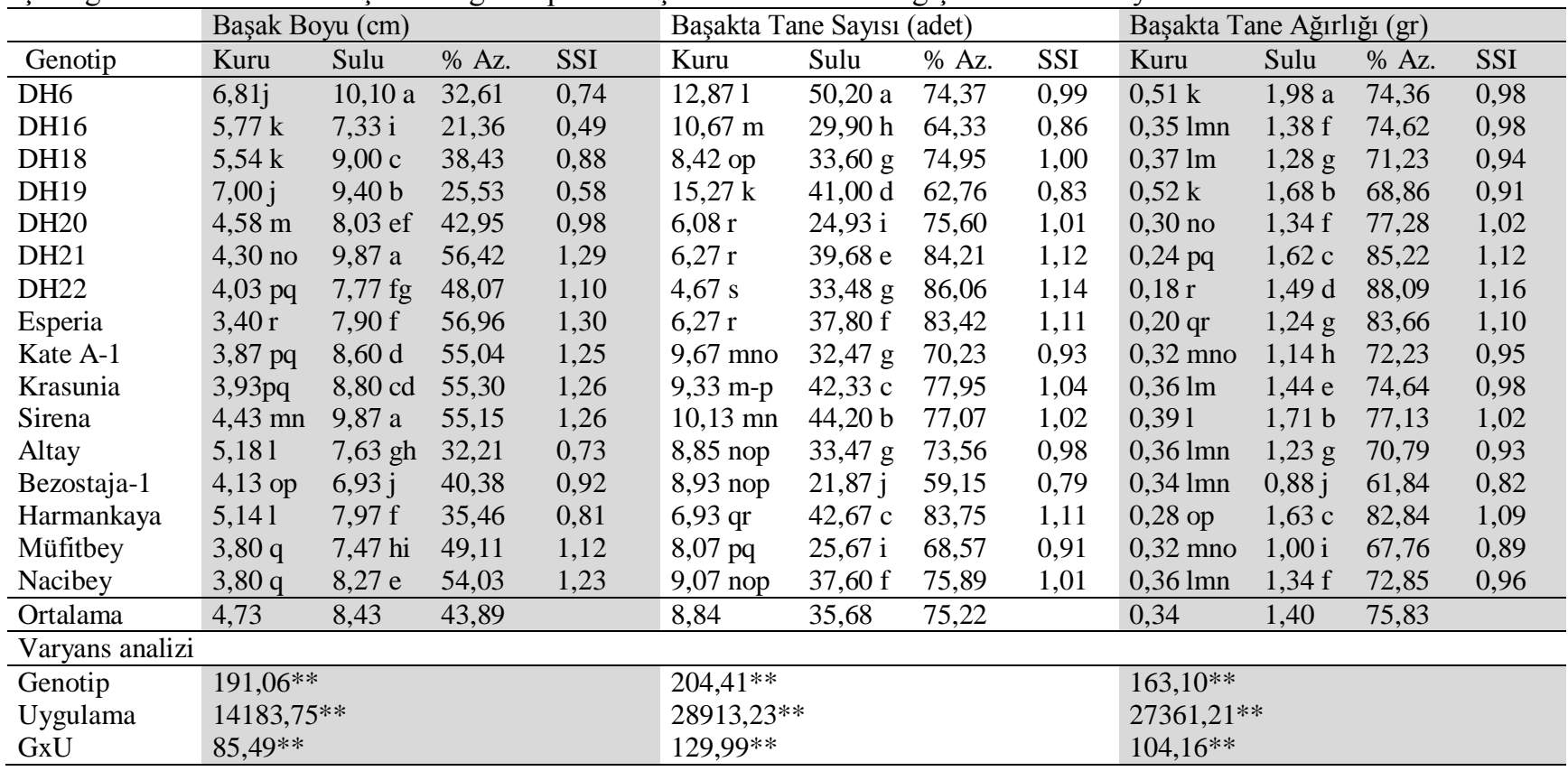

ns: önemsiz, ${ }^{*} \mathrm{p} \leq 0.05,{ }^{* *} \mathrm{p} \leq 0.01, \mathrm{G}$ : genotip, $\mathrm{U}$ : uygulama

Bin tane ağırlığında genotipler arasında önemli farklılıklar belirlenirken sulama uygulamasının etkisi önemsiz bulunmuştur (Çizelge 2). Bin tane ağırlığı yüksek olan genotiplerin stres koşullarında az tane oluşturmasına rağmen tane ağırlığını koruyabilme özelliğine sahip olduğu belirlenmiştir. Genotiplerin SSI değerleri 0,02 ile 11,25 arasında değişim göstermiş olup, SSI değeri 1'den küçük olan DH6, Esperia, Kate A-1,Altay ve Müfitbey genotiplerinin bin tane ağırlığının stres koşullarından en az derecede etkilendiği söylenebilir.
Çiçeklenme süresi bitkilerde erkenciliğin bir göstergesidir ve erkencilik de kuraklıktan kaçışta dikkate alınan bir parametredir (Sade, 1999). Genotiplerin çiçeklenme süreleri kuru koşullarda 128,33 gün (DH16) ile 136,67 gün (Müfitbey), sulu koşullarda ise 137,67 gün (DH22) ile 148,0 gün (DH6) arasında değişmektedir (Çizelge 2). Bezostaja-1 çeşidi olumsuz koşullarda çiçeklenme süresini koruyabilmiş ve 0,58 SSI değeri ile de kuraklık koşularına uyum sağlayabildiği desteklenmiştir.

Çizelge 2. Kuru ve sulu koşullarda genotiplerin bin tane ağırlığı ve çiçeklenme süresi özelliklerinin değişimi ve stres duyarlilık indeksleri

\begin{tabular}{|c|c|c|c|c|c|c|c|c|}
\hline & \multicolumn{4}{|c|}{ Bin tane ağırlı̆̆ (gr) } & \multicolumn{4}{|c|}{ Çiçeklenme süresi (gün) } \\
\hline Genotip & Kuru & Sulu & $\% \mathrm{Az}$. & SSI & Kuru & Sulu & $\% \mathrm{Az}$. & SSI \\
\hline DH6 & $39,48 \mathrm{e}-\mathrm{h}$ & 39,46 e-h & $-0,06$ & $-0,02$ & $130,67 \mathrm{pq}$ & $148,00 \mathrm{a}$ & 11,71 & 1,61 \\
\hline DH16 & $32,91 \mathrm{k}$ & $46,32 \mathrm{bc}$ & 28,95 & 11,25 & $128,33 \mathrm{~s}$ & $144,67 \mathrm{bc}$ & 11,29 & 1,56 \\
\hline DH18 & 43,88 cde & $38,21 \mathrm{f}-\mathrm{j}$ & $-14,84$ & $-5,77$ & $130,67 \mathrm{pq}$ & $140,00 \mathrm{gh}$ & 6,67 & 0,92 \\
\hline DH19 & $34,32 \mathrm{ijk}$ & $41,05 \mathrm{def}$ & 16,40 & 6,37 & $131,00 \mathrm{pq}$ & $145,67 \mathrm{~b}$ & 10,07 & 1,39 \\
\hline DH20 & $50,10 \mathrm{ab}$ & $53,78 \mathrm{a}$ & 6,84 & 2,66 & 130,33 pqr & $139,33 \mathrm{hi}$ & 6,46 & 0,89 \\
\hline DH21 & $38,30 \mathrm{f}-\mathrm{j}$ & 40,90 def & 6,34 & 2,47 & $131,33 \mathrm{p}$ & $145,67 \mathrm{~b}$ & 9,84 & 1,36 \\
\hline $\mathrm{DH} 22$ & $37,92 \mathrm{f}-\mathrm{j}$ & $44,48 \mathrm{~cd}$ & 14,75 & 5,73 & $129,33 \mathrm{rs}$ & $137,67 \mathrm{jk}$ & 6,05 & 0,83 \\
\hline Esperia & $32,38 \mathrm{k}$ & $32,81 \mathrm{k}$ & 1,31 & 0,51 & $132,67 \mathrm{o}$ & $141,00 \mathrm{fg}$ & 5,91 & 0,81 \\
\hline Katea-A1 & $32,88 \mathrm{k}$ & $35,23 \mathrm{~h}-\mathrm{k}$ & 6,69 & 2,60 & $130,67 \mathrm{pq}$ & $138,67 \mathrm{ij}$ & 5,77 & 0,79 \\
\hline Krasunia & $39,07 \mathrm{fgh}$ & $34,00 \mathrm{jk}$ & $-14,92$ & $-5,80$ & $134,67 \mathrm{n}$ & $141,67 \mathrm{ef}$ & 4,94 & 0,68 \\
\hline Sirena & $38,51 \mathrm{f}-\mathrm{j}$ & $38,63 \mathrm{f}-\mathrm{j}$ & 0,31 & 0,12 & $135,33 \mathrm{mn}$ & $142,67 \mathrm{de}$ & 5,14 & 0,71 \\
\hline Altay & 40,73 def & $36,93 \mathrm{f}-\mathrm{k}$ & $-10,30$ & $-4,00$ & $136,33 \mathrm{~lm}$ & $147,67 \mathrm{a}$ & 7,67 & 1,06 \\
\hline Bezostaja-1 & $37,81 \mathrm{f}-\mathrm{j}$ & $40,41 \mathrm{def}$ & 6,45 & 2,51 & $135,67 \mathrm{lmn}$ & $141,67 \mathrm{ef}$ & 4,24 & 0,58 \\
\hline Harmankaya & 40,29 def & $38,15 \mathrm{f}-\mathrm{j}$ & $-5,58$ & $-2,17$ & $130,00 \mathrm{qr}$ & 139,00 & 6,47 & 0,89 \\
\hline Müfitbey & $39,93 \mathrm{~d}-\mathrm{h}$ & $38,93 \mathrm{f}-\mathrm{i}$ & $-2,58$ & $-1,00$ & $136,67 \mathrm{kl}$ & $145,67 \mathrm{~b}$ & 6,18 & 0,85 \\
\hline Nacibey & $40,00 \mathrm{~d}-\mathrm{g}$ & $35,55 \mathrm{~g}-\mathrm{k}$ & $-12,53$ & $-4,87$ & $133,33 \mathrm{o}$ & $143,67 \mathrm{~cd}$ & 7,19 & 0,99 \\
\hline Ortalama & 38,66 & 39,68 & 2,57 & & 132,31 & 142,67 & 7,26 & \\
\hline \multicolumn{9}{|c|}{ Varyans analizi } \\
\hline Genotip & $17,69 * *$ & & & & $78,62 * *$ & & & \\
\hline Uygulama & $4,39 \mathrm{~ns}$ & & & & $5613,84 * *$ & & & \\
\hline $\mathrm{GxU}$ & $6,70 * *$ & & & & $39,15 * *$ & & & \\
\hline
\end{tabular}

ns: önemsiz, ${ }^{*} \mathrm{p} \leq 0.05,{ }^{*} \mathrm{p} \leq 0.01, \mathrm{G}$ : genotip, U: uygulama 
Son yllarda özellikle antioksidan enzimlerin ölçülmesiyle hem kurak koşullardaki bitkilerin fizyolojik mekanizmaları daha iyi anlaşılabilmekte hem de çeşitler arasındaki farklılıklar ortaya konulabilmektedir. Çeşitli araştırıcılar kurak koşullarda özellikle kurağa hassas genotiplerde antioksidan enzim aktivitesinin arttığını belirlemişlerdir (Ge ve ark., 2006; Simova-Stoilova ve ark., 2009; Kireçci, 2012). Katalaz ve GR enzim aktivitelerinin genotiplere ve uygulamalara göre değişimi sırasıyla Şekil 1a ve Şekil $1 \mathrm{~b}$ 'de görülmektedir. Genotiplerin CAT ve GR aktiviteleri genellikle kuru koşullarda daha yüksek bulunmuştur. Ayrıca DH16, DH18 ve DH22 genotiplerinde sulu koşullarda CAT aktivitesi daha yüksek olurken (Şekil 1a), DH18, DH20, Kate A-1, Sirena, Müfitbey ve Nacibey genotiplerinde GR aktivitesi sulu koşullarda yüksek bulunmuştur (Şekil 1b). $\mathrm{Bu}$ durumun genotiplerin stres koşullarına yanıtlarının farklı olmasından kaynaklandığı söylenebilir. Benzer şekilde Simova-Stoilova ve ark. (2009), Kireçci (2012), Osipava ve ark. (2013) de CAT ve GR aktivitesinin kurak koşullar altında bazı buğday genotiplerinde yüksek, bazılarında düşük bulduklarını bildirmişlerdir.

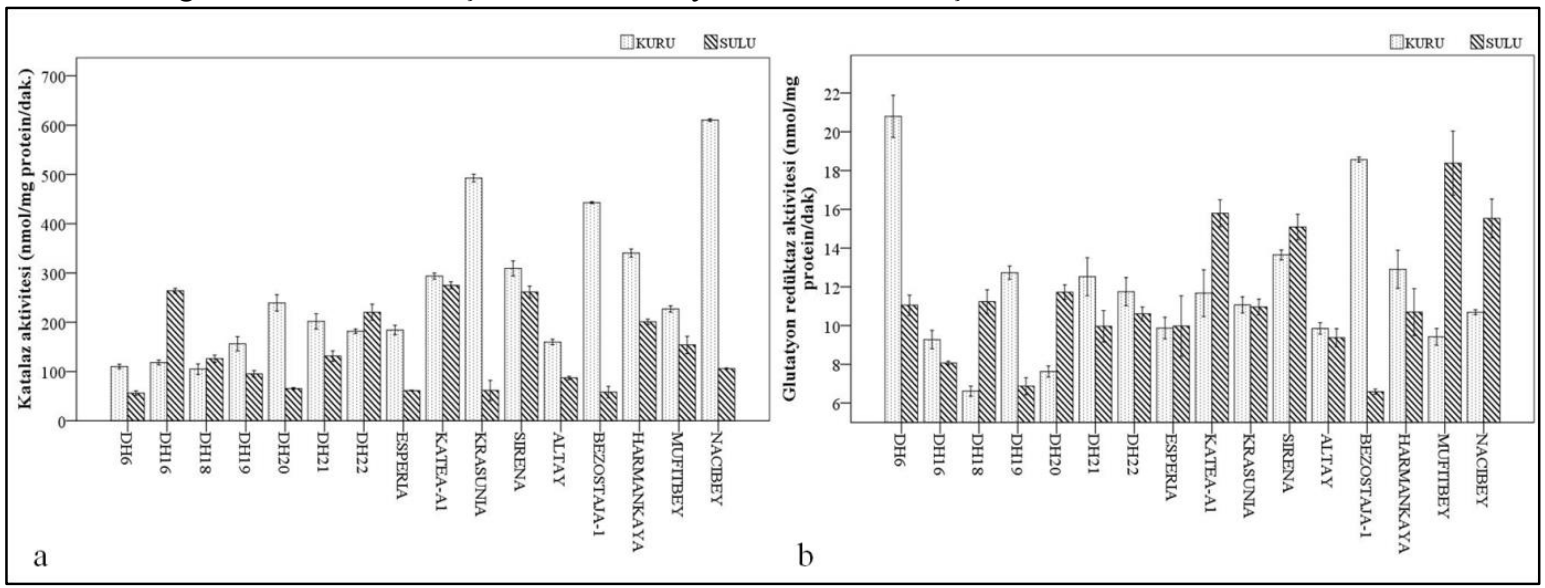

Şekil 1. Kuru ve sulu koşullarda genotiplerin CAT (a) ve GR (b) enzim aktivitelerindeki değişimler.

Katalaz enzim aktivitesi ile çiçeklenme süresi, başak boyu, başakta tane sayısı ve ağırlığı arasında negatif ve önemli korelasyon belirlenirken, GR aktivitesi ile bin tane ağırlığı arasında negatif ve önemli korelasyon saptanmıştır (Çizelge 3). Osipava ve ark. (2011) ve Osipava ve ark. (2013) CAT aktivitesi ile başakta tane sayıs1 arasında pozitif ve önemli korelasyon tespit etmişlerdir. Bu çalışmada CAT aktivitesinin düşük, çiçeklenme süresi, başak boyu, başakta tane sayısı ve ağırlığının yüksek ve GR aktivitesinin düşük, bin tane ağırlığının yüksek olacağı anlamına gelen bu sonuçlar, enzim aktivitelerinin sulu koşullarda düşük bulunmasından kaynaklanmış olabilir. Bu durumda, enzim aktivitelerinin seviyelerindeki artısıın kuraklık toleransını arttırabileceği söylenebilir. Ramachandra ve ark. (2004), kuraklık stresinin bitkilerde ozmotik etki oluşturarak, büyüme inhibisyonundan hücrenin ozmotik potansiyelini arttırıcı bazı toksik olmayan bileşiklerin sentezine kadar birçok cevabı uyarabileceğini ancak bazı antioksidan enzimlerin aktivitelerinin sürekliliğini sağlayarak kuraklık toleransının artabileceğini belirtmiştir. Kuraklık stresine maruz kalan bitkiler antioksidan savunma sistemlerinin bazılarını veya tamamını kullanarak çevresel streslerin üstesinden gelebilirler (Srivalli ve ark., 2003).

Cizelge 3. Enzim aktiviteleri ile verim komponentleri arasındaki korelasyon katsayıları ve önemlilikleri

\begin{tabular}{lll}
\hline Verim Komponentleri & Katalaz & Glutatyon Redüktaz \\
\hline Ciç̧eklenme süresi & $-0.376^{* *}$ & $-0.056 \mathrm{~ns}$ \\
Başak boyu & $-0.574^{* *}$ & $0.027 \mathrm{~ns}$ \\
Başakta tane sayısı & $-0.464^{* *}$ & $-0.027 \mathrm{~ns}$ \\
Başakta tane ağırlığ 1 & $-0.457^{* *}$ & $-0.063 \mathrm{~ns}$ \\
Bin tane ağırlı̆ 1 & $-0.012 \mathrm{~ns}$ & $-0.225^{*}$ \\
\hline ns: önemsiz ${ }^{*}<00.05, * * \mathrm{p}<0.01$ & &
\end{tabular}

Sonuç olarak; çalışmada kullanılan buğday genotiplerinde kurak koşullar çiçeklenme süresi ve başak özelliklerinde önemli derecede azalmaya sebep olurken, bin tane ağırlığını etkilememiş̦tir. Katalaz ve GR enzim aktiviteleri genotiplere göre değişmekle birlikte, kurak koşullarda önemli derecede artış göstermiştir. Ayrıca incelenen özelliklerle CAT ve GR aktiviteleri arasında negatif ve önemli korelasyonlar saptanmıştır. Bunun dışında tüm başak özelliklerinde SSI bakımından 1'den küçük değere sahip olan ve stres koşullarında özellikle CAT aktivitesini koruyabilen DH6 ve DH19 genotipleri ile Bezostaja-1 çeşidinin, kuraklığa toleransı geliştirmek için yapılacak ıslah programlarında ebeveyn olarak kullanılabileceği sonucuna varılmıştır. Ek olarak, belirlenen toleranslı ve hassas çeşitler arasında yapılacak melezlemelerden elde edilecek populasyonda bu enzim mekanizmalarını etkileyen kalıtım mekanizmalarının da araştırılması faydalı olacaktır. 


\section{KAYNAKLAR}

Allen R 1995. Dissection of Oxidative Stress Tolerance Using Transgenic Plants, Plant Physiology, 107:1049-1054.

Aydoğan S, Sade B 2017. Ekmeklik Buğday Çeşitlerinin Verim ve Verim Öğeleri ile Bazı Kalite Özelliklerinin Belirlenmesi, Tarla Bitkileri Merkez Araştırma Enstitüsü Dergisi, 26 (1): 24-30

Blum A 1988. Plant Breeding for Stress Environments, Boca Raton, FL.CRF Press.

Cakmak I, Marschner H 1992. Magnesium Deficiency and High-Light Intensity Enhance Activities of Superoxide Dismutase, Ascorbate Peroxidase and Glutathione Reductase in Bean Leaves, Plant Physiol., 98: 1222-1227.

Clarke JM, De Pauw RM, Townley-Smith TM 1992. Evaluation of Methods for Quantification of Drought Tolerance in Wheat, Crop Sci. 32: 728732.

Contour-Ansel D, Torres-Franklin LM, Cruz de Carvalho MH, D'arcy-Lameta A, Zuily- Fodil Y 2006. Glutathione Reductase in Leaves of Cowpea: Cloning of Two cDNAs, Expression and Enzymatic Activity under Progressive Drought Stress, Desiccation and Abscisic Acid Treatment, Ann. of Bot. 98: 1279-1287.

Dencic S, Kastori R, Kobiljski B, Duggan B 2000. Evaluation of Grain Yield and its Components in Wheat Cultivars and Landracesunder Near Optimal and Drought Conditions, Euphytica, 113: 43-52.

Farooq M, Wahid A, Kobayashi N, Fujita D, Basra SMA 2009: Plant Drought Stress: Effects, Mechanisms and Management, Agron. Sust. Dev. 29: 185-212.

Fischer RA, Maurer R 1978. Drought Resistance in Spring Wheat Cultivars. I. Grain Yield Responses, Austr. J. Agric. Res., 29: 897-912.

Ge, TD, Sui FG, Bai LP, Lu YY, Zhou GS 2006. Effects of Water Stress on the Protective Enzyme Activities and Lipid Peroxidation in Roots and Leaves of Summer Maize, Agricultural Sciences in China, 5(4): 291-298.

Huseynova IM, Rustamova SM, Suleymanov SY, Aliyeva DR, Mammadov AC, Aliyev JA 2016. Drought-Induced Changes in Photosynthetic Apparatus and Antioxidant Components of Wheat (Triticum durum Desf.) Varieties. Photosynthesis Research, 130(1-3): 215-223.

Kireçci OA 2012. Kuraklık Stresine Maruz Bırakılan Triticum aestivum L. (Buğday) Çeşitlerinde Sinyal İletiminde Rol Oynayan Bazı Biyomoleküllerin Araştırılması. İnönü Üniversitesi Fen Bilimleri Enstitüsü, Doktora tezi, $245 \mathrm{~s}$.

Moran JF, Becana M, Titrbe-Ormaetxe I, Frechilla S, Klucas RV, Aparicio-Tejo P 1994. Drought Induces Oxidative Stress in Pea Plants, Planta, 194: 346-352.

Osipova SV, Permyakov AV, Permyakova MD, Pshenichnikova TA, Börner A 2011. Leaf Dehydroascorbate Reductase and Catalase Activity is Associated with Soil Drought Tolerance in Bread
Wheat, Acta Physiologiae Plantarum, 33(6): 21692177.

Osipova SV, Permyakov AV, Permyakova MD, Pshenichnikova TA, Genaev MA, Börner A 2013. The Antioxidant Enzymes Activity in Leaves of Inter-Varietal Substitution Lines of Wheat (Triticum aestivum L.) with Different Tolerance to Soil Water Deficit, Acta Physiologiae Plantarum, 35(8): 24552465.

Öztürk A 1999. Kuraklığın Kışlık Buğdayın Gelişmesi ve Verimine Etkisi. Tr. J. of Agric. and Forestry Sciences, 2: 199-237.

Pastori G, Foyer CH, Mullineaux P 2000. Low Temperature-Induced Changes in the Distribution of $\mathrm{H}_{2} \mathrm{O}_{2}$ and Antioxidants between the Bundle Sheath and Mesophyll Cells of Maize Leaves, J Exp Bot, 51: 107-113.

Ramachandra Reddy A, Chaitanya KV, Jutur PP, Sumithra K 2004. Differential Antioxidative Responses to Water Stress Among Five Mulberry (Morus alba L.) Cultivars, Environ. Exp. Bot., 52: 33-42.

Rao MV, Paliyath G, Ormrod DP 1996. Ultraviolet-Band Ozone-Induced Biochemical Changes in Antioxidant Enzymes of Arabidopsis thaliana. Plant Phsiol, 110:125-136.

Richards RA, Condon AG, Rebetzke GJ 2001. Traits to Improve Yield in Dry Environments, (Application of Physiology in Wheat Breeding, Mexico: CIMMYT: Ed. Reynolds MP, Ortiz-Monasterio JI, McNab A), 88-101.

Sade B 1999. Tahıl Islahı (Buğday ve Mısır). Selçuk Üniv. Ziraat Fak Yay. No:31

Sharma P, Dubey RS 2005, Lead Toxicity in Plants. Braz. J. Plant Physiol. 17: 35-52.

Sharma SC, Thakur KS 2004. Selection Criteria for Drought Tolerance in Spring Wheat ( $T$. aestivum L.). 4 th Int. Crop Sci. Congress. 26 September-1 October, Brisbone, Australia

Simova-Stoilova L, Demirevska K, Petrova T, Tsenov N, Feller U 2009. Antioxidative Protection and Proteolytic Activity in Tolerant and Sensitive Wheat (Triticum aestivum L.) Varieties Subjected to LongTerm Field Drought, Plant Growth Regulation, 58(1): 107-117.

Srivalli B, Sharma G, Khanna-Chopra R 2003. Antioxidative Defence System in Upland Rice Cultivar Subjected to Increasing Intensity of Water Stress Followed by Recovery, Physiol. Plant., 119: 503-512.

Sudhakar C, Lakshmi A, Giridarakumar S 2001. Changes in the Antioxidant Enzyme Efficacy in Two High Yielding Genotypes of Mulberry (Morus alba L.) Under NaCl Salinity. Plant Sci. 161:613-619.

Tosun O, Yurtman N 1973. Ekmeklik Buğdaylarda (Triticum aestivum L. Em Thell) Verime Etkili Morfolojik ve Fizyolojik Özellikler. Ankara Üniv. Zir. Fak. Y1llığ 1 23: 414-434. 